\title{
Qualitative attributes and postharvest conservation of green ears of maize grown on different cover crops in organic no-till system ${ }^{1}$
}

\author{
Luiz Fernando Favarato²*, Jacimar Luiz de Souza², João Carlos Cardoso Galvão ${ }^{3}$, Caetano Marciano de Souza ${ }^{3}$, \\ José Mauro de Souza Balbino², Rogério Carvalho Guarçoni ${ }^{2}$
}

10.1590/0034-737X201663040014

\begin{abstract}
Postharvest quality of sweet maize varies depending on the type of seed, soil, quality of fertilizer, climatic conditions, and stage of maturation. This study aimed to evaluate the post-harvest quality and shelf life of green ears of maize grown on three soil covers in organic no-till sytem. The study was conducted in the municipality of Domingos Martins, $\mathrm{ES}\left(20^{\circ} 22^{\prime} 16.91^{\prime \prime} \mathrm{S}\right.$ and $\left.41^{\circ} 03^{\prime} 41.83^{\prime \prime} \mathrm{W}\right)$. The experiment was arranged in a randomized block design with six replications and five treatments, consisting of three cover crops in organic no-till system: black-oat straw, white lupin, oat/lupin intercrop and two systems, organic and conventional, without straw. Maize double hybrid AG-1051 was sown in a spacing of $1.00 \times 0.20 \mathrm{~m}$. The variables evaluated included relative percentage of grain, straw and cob, $\mathrm{pH}$, titratable acidity, soluble solids, grain moisture and shelf life. The use of different straws in the organic no-till system does not influence the postharvest quality of green ears. Ears packed in polystyrene trays with plastic film are suitable for marketing until the fifth day of storage at room temperature.
\end{abstract}

Key words: Zea mays; shelf life; organic agriculture.

\section{RESUMO}

\section{Atributos qualitativos e conservação pós-colheita de espigas de milho-verde cultivado sobre diferentes coberturas de solo no sistema de plantio direto orgânico}

A qualidade pós-colheita do milho-verde varia de acordo com o tipo de semente, de solo, da qualidade do fertilizante utilizado, das condições climáticas e do estágio de maturação. Objetivou-se avaliar a qualidade pós-colheita e o tempo de prateleira de espigas de milho-verde cultivado sobre três coberturas de solo no sistema plantio direto orgânico. O trabalho foi desenvolvido no município de Domingos Martins-ES ( $20^{\circ} 22^{\prime} 16.91$ "S e $\left.41^{\circ} 03^{\prime} 41.83^{\prime \prime} \mathrm{O}\right)$, sendo disposto em delineamento de blocos casualizados, com seis repetições e cinco tratamentos, constituídos por três coberturas de solo no sistema plantio direto orgânico, palha de aveia-preta, tremoço-branco e consórcio aveia/tremoço e dois sistemas sem palhada, sendo um orgânico e um convencional. Foi utilizado o híbrido duplo de milho AG-1051 no espaçamento de 1,00 x 0,20 m. Foram realizadas avaliações de percentual relativo de grãos, palha e sabugo, pH, acidez titulável total, sólidos solúveis totais, umidade dos grãos e tempo de prateleira. $\mathrm{O}$ uso de diferentes palhadas no sistema plantio direto orgânico não influencia a qualidade pós-colheita do milho-verde. As espigas embaladas em bandeja de poliestireno expandido com filme de PVC apresentam-se aptas a comercialização até o quinto dia de armazenamento em temperatura ambiente.

Palavras-chave: Zea mays; tempo de prateleira; agricultura orgânica.

\footnotetext{
Submitted on February $24^{\text {th }}, 2015$ and accepted on May 16 $6^{\text {th }}, 2016$.

This work is part of the first author doctor's thesis. Work funded by CNPq.

${ }^{2}$ Centro Regional Centro-Serrano, Instituto Capixaba de Pesquisa, Assistência Técnica e Extensão Rural, Venda Nova do Imigrante, Espírito Santo, Brazil. luiz.favarato@incaper.es.gov.br; jacimarsouza@yahoo.com.br; balbino@incaper.es.gov.br; rogerio.guarconi@ incaper.es.gov.br

${ }^{3}$ Universidade Federal de Viçosa, Departamento de Fitotecnia, Viçosa, Minas Gerais, Brasil. jgalvao@ufv.br; cmsouza@ufv.br

*Corresponding author: luiz.favarato@incaper.es.gov.br
} 


\section{INTRODUCTION}

Maize is the third most consumed cereal in the world and is considered an important source of carbohydrates, thus constituting an energy giving food. It is also a source of oil and fiber and provides small amounts of vitamins B1, B2 and E. In addition to the common-maize, there are varieties of sweet maize, which for having different sugar composition in the grains, have sweeter flavor and creamy texture more suitable for consumption as vegetables (Matos et al., 2007).

Production of green maize has increased significantly because of its profitability, since green maize has greater commercial value than dry maize grain. In addition, maize farming uses mostly family labor, contributing to job creation in small and medium farms, particularly at harvest time, which is performed manually (Cruz et al., 2006). Another factor contributing to the growth of green maize production is the more diversified use of the product by the market, as it can be sold for consumption in several forms, as fresh produce, cooked or as ingredient in the manufacture of different products in the Brazilian cuisine (Matos et al., 2007).

Green maize is highly perishable, in addition to nutrients, it can also lose market attributes such as appearance and freshness in a few hours. Because it is harvested before maturation, physiologically its organs contain tissues which are not fully developed (Kays, 1991). The metabolic activity in produce under these conditions is high, greatly accelerating physiological and biochemical changes. The result is deterioration, senescence and death of tissue mostly due to intense water loss (Finger \& Vieira, 1997).

Postharvest quality of green maize, is linked to aspects of plant physiology involving mainly its chemical composition, which varies according to the type of seed, soil, fertilizer quality, climatic conditions and maturation stage at harvest (Marcos et al., 1999).

Pinho et al. (2008) found that the post-harvest quality of green maize grown in organic and conventional production systems was influenced by the management adopted, with higher average $\mathrm{pH}$ and lower titratable acidity in green seeds grown in the organic system.

However, there are not enough studies to allow clear conclusions on the impact of production systems on food quality, since failures in the conduction of experiments compromise a valid comparison of green maize characteristics in each system production. Therefore, this study aimed to evaluate the post-harvest quality and shelflife of green ears of maize grown on three cover crops in organic no-till system.

\section{MATERIAL AND METHODS}

This work was developed in the municipality of Domingos Martins, ES (20 $22^{\prime} 16.91 " \mathrm{~S}$ and $\left.41^{\circ} 03^{\prime} 41.83^{\prime \prime} \mathrm{W}\right)$, $950 \mathrm{~m}$ altitude. In this region, the average annual rainfall is $1,800 \mathrm{~mm}$, the average maximum air temperature in the warmer months is between 26.7 and $27.8{ }^{\circ} \mathrm{C}$ and the average minimum temperature in the cooler months is between 8.5 and $9.4{ }^{\circ} \mathrm{C}$ (Espírito Santo, 1999).

The experiment was conducted in a dystrophic clayey Oxisol (Embrapa, 1999), in an area that has been cultivated in organic no-till system since 2009, The area is divided into strips physically isolated by concrete slabs buried at $0.60 \mathrm{~m}$ depth, cultivated with successive cabbage crops on summer cover crops (sunn hemp, maize and intercrop of both species) and eggplant on winter cover crops (white lupin, oat and intercrop of both species). The experiment was carried out from July 2013 to February 2014. Chemical analysis of soil was carried out at 0-20 cm depth: $\mathrm{pH}$ (6.5), $\mathrm{P}\left(160.6 \mathrm{mg} \mathrm{dm}^{-3}\right), \mathrm{K}+\left(290.2 \mathrm{mg} \mathrm{dm}^{-3}\right), \mathrm{Ca}^{2+}(6.0 \mathrm{cmolc} \mathrm{dm}-$ 3), $\mathrm{Mg}^{2+}\left(1.2 \mathrm{cmolc} \mathrm{dm}^{-3}\right) \mathrm{Al}\left(0.0 \mathrm{cmolc} \mathrm{dm}^{-3}\right), \mathrm{H}+\mathrm{Al}(2.3$ cmolc dm$\left.{ }^{-3}\right), \mathrm{SB}\left(8.1 \mathrm{cmolc} \mathrm{dm}^{-3}\right), \mathrm{t}\left(8.1 \mathrm{cmolc} \mathrm{dm}^{-3}\right), \mathrm{T}(10.4$ cmolc $\left.\mathrm{dm}^{-3}\right), \mathrm{V}(77.5 \%)$ and $\mathrm{MO}\left(4.5 \mathrm{dag} \mathrm{kg}^{-1}\right)$.

The experiment was arranged in a randomized block design with six replications and five treatments, totaling 30 experimental $6.0 \times 4.0 \mathrm{~m}$ plots, with total area of $24 \mathrm{~m}^{2}$ and harvest area of $16 \mathrm{~m}^{2}$. The treatments consisted of three cover crops in organic no-till system (SPD) (G - SPD organic with grass straw, L - SPD organic with legume straw; G + L - SPD organic with grass + legume straws) and two systems, organic and conventional, with soil loosening and without cover crop (SC - conventional system without straw; $\mathrm{SO}$ - organic system without straw). The cover crops used were black oat (Avena strigosa Schreb), white lupin (Lupinus albus L.) and intercrop of both species.

The cover crops were sown on 07.05.2013, in rows spaced $0.33 \mathrm{~m}$ apart, with seed density in the single system of 144 grams of black oat $\left(60 \mathrm{~kg} \mathrm{ha}^{-1}\right)$ per plot and 204 grams of lupin $\left(85 \mathrm{~kg} \mathrm{ha}^{-1}\right)$ per plot. In the intercrop, the seeding rates and seed quantities have been halved because the planting was carried out in alternating rows.

At 103 days after sowing, at full bloom, the cover crops were mowed with a costal weeder. Then, organic compost was applied at the rate of $1.5 \mathrm{~kg} \mathrm{~m}^{-1}$ (dry matter), evenly distributed and broadcasted on all experimental plots with organic management, preceding the maize sowing. The compost chemical characteristics were: $\mathrm{N}, \mathrm{P}, \mathrm{K}, \mathrm{Ca}$ and $\mathrm{Mg} ; 1,5,0,7,1,7,1,8$ and $0,3 \mathrm{dag} \mathrm{kg}^{-1}$, respectively; $\mathrm{Zn}, \mathrm{Fe}$, $\mathrm{Mn}, \mathrm{Cu}$ and B: 100, 15.100, 281, 92 and $32 \mathrm{mg} \mathrm{kg}^{-1}$; CO, $33 \%$; and $\mathrm{C} / \mathrm{N}, 13$. There was no use of additional topdressing for plots under organic cultivation. 
In the plots with conventional tillage, without cover crop, the fertilization of maize at planting was carried out with $800 \mathrm{~kg} \mathrm{ha}^{-1}$ of the formula 04-14-08. At 35 days after maize emergence, $100 \mathrm{~kg} \mathrm{ha}^{-1} \mathrm{~N}$ was broadcasted on the plots using ammonium sulfate.

Hybrid AG-1051, for consumption as green maize, was sown with a manual seeder at the same day the cover crops were managed, at the spacing of $1.00 \mathrm{~m}$ between rows and $0.20 \mathrm{~m}$ between plants, and density of three seeds per hole. Later, seedlings were removed, one plant per hole, establishing a population of 50,000 plants per hectare. Sampling for the determination of qualitative parameters was performed with a random harvest of ten ears per plot, with grain at the milky stage, based on the market requirements of maize green ears for human consumption.

Ears were harvest manually in the early hours of the morning, with straw, and taken to the laboratory. Agronomic characteristics of maize were determined: samples were weighed on an analytical scale to obtain the weight of ears with husk (PP) (g), then all the ears of each plot were husked, washed sequentially in tap water and distilled water, and then dried on paper towel and weighed to obtain the weight of husked ears (PD) (g). Kernels were cut off the cobs with a knife and weighed to obtain kernel fresh weight $(\mathrm{PG})(\mathrm{g})$. Cob (PS) $(\mathrm{g})$ and straw $(\mathrm{P})(\mathrm{g})$ weights were also determined.

The relative percentage of grain (PRG), straw (PRP) and cob (PRS) were determined using the formulas: $\mathrm{x}=$ $100 \times$ PG / PP; PRP = $100 \times$ P /PP e PRS = $100 \times$ PS / PP.

For determination of physicochemical characteristics, the samples of green kernels were divided into four parts, homogenized in a blender, and immediately evaluated for titratable acidity, soluble solids, and grain moisture. The $\mathrm{pH}$ was determined with a digital $\mathrm{pH}$ meter (Quimis ${ }^{\circledR}, \mathrm{Q}-$ 400HM portable model).

Titratable acidity was obtained by titration of samples consisting of $20 \mathrm{ml}$ of the extract diluted in $40 \mathrm{ml}$ of distilled water with $0.1 \mathrm{~mol} \mathrm{~L}^{-1} \mathrm{NaOH}$, until $\mathrm{pH}$ 8.1. The result was expressed in \% of malic acid, which is considered as the organic acid of greater amount in maize.

For determination of total soluble solids, $1 \mathrm{ml}$ aliquots of the sample was centrifuged in an Eppendorf ${ }^{\circledR}$ 5417R centrifuge for 15 minutes at $13,000 \mathrm{rpm}$, at $20^{\circ} \mathrm{C}$, and the supernatant was read with a digital refractometer (Atago ${ }^{\circledR}$, PAL-1), according to Horwitz (2005). The analyses were conducted at the INCAPER Laboratory of Postharvest Physiology, in triplicate.

To evaluate shelf life, ten ears were harvested from each treatment, washed in tap water, husked, and then disinfested in water with $20 \mathrm{ppm}$ free chlorine, for $15 \mathrm{~min}$. Then, three ears of each plot were packed in polystyrene trays, sealed with PVC commercial film and stored in BOD at $25{ }^{\circ} \mathrm{C}$ (simulating the room temperature) and $50 \%$ relative humidity. The experiment was arranged in a split plot randomized block design with six replications; with the the five treatments in the plots and the four storage times in the subplots.

For the determination of mass loss, the ears were weighed on a precision scale at the beginning and at 3,6 and 9 days of storage, the results were expressed as percentage of fresh mass loss using the following formula: $\mathrm{PTT}=100$ - (PF x 100 / PI), where PTT = fresh mass loss $(\%) ; \mathrm{PF}=$ weight of the final fresh mass ( $\mathrm{g}) ; \mathrm{PI}=$ weight of initial fresh mass $(\mathrm{g})$.

Data relative to the parameters malic acid (\%), ${ }^{\circ}$ brix, humidity (\%), grain relative percentage of (PRG), straw relative percentage (PRP), relative percentage of cobs (PRS) and mass loss (\%) were transformed using the angular transformation $\mathrm{y}=\operatorname{arcseno}(\operatorname{root}(\mathrm{x} / 100))$.

Data were submitted to analysis of variance using the F-test, regression models were tested by the F test, the slope coefficients of the regression models were tested by the test, and means were compared using the Tukey test $\mathrm{p}>0.05$ using the software SigmaPlot 10.0.

\section{RESULTS AND DISCUSSION}

Post-harvest characteristics of ears were not influenced by the different production systems (Table 1). However, the average $\mathrm{pH}$ (7.59) observed in this study was relatively close to those reported in the literature for sweet maize, which is classified as a slightly acid food and therefore favorable to the multiplication of microorganisms (Pinho et al., 2008). The grain moisture was high with mean of $81.8 \%$. The green maize is considered a highly perishable food due to its high water content, which makes its marketing period very limited (Silva et al., 1997). The higher $\mathrm{pH}$ and lower acidity obtained for the green maize suggest greater susceptibility to potential spoilage and pathogenic microorganisms.

The mean soluble solids $\left(7.69^{\circ}\right.$ brix) found for green maize can be considered low when compared to the values found by Pinho et al. (2008) for sweet maize, obtaining 15.83 and $14.50^{\circ}$ brix, respectively, for cultivars SWB and VIVI.

The soluble solids content is used as an indirect measure of sugar content, as it increases with the accumulation of sugars in the ear. Its value is not the exact content of sugars, since other substances such as organic acids, vitamins, phenolic compounds, pectin, etc, are also dissolved (Chitarra, 2002).

The low content of soluble solids found in this study characterizes a variety of starchy green maize, which is a characteristic desired by the consumer, since these ears will be used for making products such as porridge, 
"pamonha", "curau", among others, requiring starch, which will allow the product to reach the ideal consistency at the time of preparation.

The relative percentage of grain, straw and cobs, have not changed with the cultivation of maize in different production systems, with means of $31.34 ; 38.21$ and $30.42 \%$, for relative percentage of grain, straw, and cob, respectively (Table 2). Pinho et al. (2008), working with different cultivars of green and sweet maize in organic and conventional farming, obtained similar values for the same variety used in this work, AG1051, with 31.95; 40.44 and $27.60 \%$ for relative percentage of grain, straw, and cob, respectively.

The higher relative percentage of straw found for the hybrid AG1051 provides a suitable characteristic for making "pamonha", since it requires straw for its preparation. Furthermore, according to Albuquerque (2008), the ideal cultivars for production of green maize must provide good husk, characterized by good integrity and production of husk, which favors the maintenance of grain moisture and better ear conservation.

The mass loss of maize cobs increased linearly with the time of storage (Figure 1); however, there was no significant difference between the treatments for the different times of storage evaluated (Table 3).

According to Chitarra \& Chitarra (2005), the main factor responsible for mass loss during storage of fruits and vegetables is transpiration, which is closely related to the respiratory process of the product. Moisture losses from $3 \%$ to $6 \%$ are sufficient to cause a marked decline in quality; however, some products are still marketable with moisture losses of up to $10 \%$. In the case of green maize, Kays (1991) considers $7 \%$ as maximum mass loss allowed.

In this work, it was found mass loss of $7 \%$, when the cobs were stored for 6 days. Henz et al. (1996) evaluated the use of plastic films in green maize postharvest conservation and concluded that packaging with PVC film was efficient to avoid excessive losses of fresh mass in maize stored at $8{ }^{\circ} \mathrm{C}$ and $24{ }^{\circ} \mathrm{C}$, while also maintaining good appearance. Mamede et al. (2009), working with storage of ears of maize hybrid AG 1051 with plastic film, at different temperatures, found that the ears remained suitable for marketing up to six days of storage at temperatures between $5{ }^{\circ} \mathrm{C}$ and $8^{\circ} \mathrm{C}$, with $3 \%$ mass loss.

However, unpleasant odor was verified in the packages of maize green ears from the fifth day of storage, confirming

Table 1: Means of characteristics $\%$ malic acid, ${ }^{\circ}$ brix, $\mathrm{pH}$ and grain moisture of maize ears grown in different planting systems. INCAPER, Domingos Martins-ES, 2014

\begin{tabular}{lllll}
\hline Treatment & \multicolumn{1}{c}{ Malic acid } & \multicolumn{1}{c}{${ }^{\circ}$ Brix } & pH & Moisture $(\%)$ \\
\hline SC & $0.0251(0.0628) \mathrm{a}$ & $0.276(7.45) \mathrm{a}$ & $7.65 \mathrm{a}$ & $1.133(82) \mathrm{a}$ \\
SO & $0.0276(0.0759) \mathrm{a}$ & $0.282(7.75) \mathrm{a}$ & $7.59 \mathrm{a}$ & $1.107(80) \mathrm{a}$ \\
$\mathrm{G}$ & $0.0271(0.0734) \mathrm{a}$ & $0.285(7.90) \mathrm{a}$ & $7.56 \mathrm{a}$ & $1.095(79) \mathrm{a}$ \\
$\mathrm{L}$ & $0.0242(0.0584) \mathrm{a}$ & $0.280(7.63) \mathrm{a}$ & $7.64 \mathrm{a}$ & $1.173(85) \mathrm{a}$ \\
$\mathrm{G}+\mathrm{L}$ & $0.0268(0.0720) \mathrm{a}$ & $0.282(7.72) \mathrm{a}$ & $7.59 \mathrm{a}$ & $1.146(83) \mathrm{a}$ \\
\hline Mean & $0.0261(0.0684)$ & $0.281(7.69)$ & 7.60 & $1.130(82)$ \\
\hline CV $(\%)$ & 10.00 & 2.48 & 1.17 & 2.76 \\
\hline
\end{tabular}

Values in the column were transformed by the function $\mathrm{y}=\arcsin [$ ["(x/100)]. Original means in brackets. Means followed by the same lower case letter in the column are not significantly different by the Tukey test at 5\% probability. SC - conventional system without straw; SO - organic system without straw; G - SPD organic system with grass straw; L - SPD organic system with legume straw; G + L - SPD organic system with grass + legume straw.

Table 2: Means of the characteristics grain relative percentage (PRG), straw relative percentage (PRP), and cob relative percentage (PRS) of maize green ears grown in different planting systems. INCAPER, Domingos Martins-ES, 2014

\begin{tabular}{llll}
\hline Treatment & \multicolumn{1}{c}{ PRG } & \multicolumn{1}{c}{ PRP } & PRS \\
\hline SC & $0.624(34.14) \mathrm{a}$ & $0.643(35.98) \mathrm{a}$ & $0.576(29.67) \mathrm{a}$ \\
SO & $0.594(31.30) \mathrm{a}$ & $0.658(37.37) \mathrm{a}$ & $0.592(31.14) \mathrm{a}$ \\
$\mathrm{G}$ & $0.593(31.28) \mathrm{a}$ & $0.664(38.02) \mathrm{a}$ & $0.586(30.57) \mathrm{a}$ \\
$\mathrm{L}$ & $0.582(30.19) \mathrm{a}$ & $0.687(40.22) \mathrm{a}$ & $0.574(29.48) \mathrm{a}$ \\
$\mathrm{G}+\mathrm{L}$ & $0.574(29.50) \mathrm{a}$ & $0.679(39.42) \mathrm{a}$ & $0.590(30.94) \mathrm{a}$ \\
\hline Mean & $0.593(31.27)$ & $0.666(38.20)$ & $0.584(30.36)$ \\
\hline CV $(\%)$ & 7.27 & 4.08 & 6.83 \\
\hline
\end{tabular}

Values in the column were transformed by the function $\mathrm{y}=\arcsin [$ ["(x/100)]. Original means in brackets. Means followed by the same lower case letter in the column column are not significantly different by the Tukey test at $5 \%$ probability. SC - conventional system without straw; SO - organic system without straw; G - SPD organic system with grass straw; L - SPD organic system with legume straw; G + L - SPD organic system with grass + legume straw. 


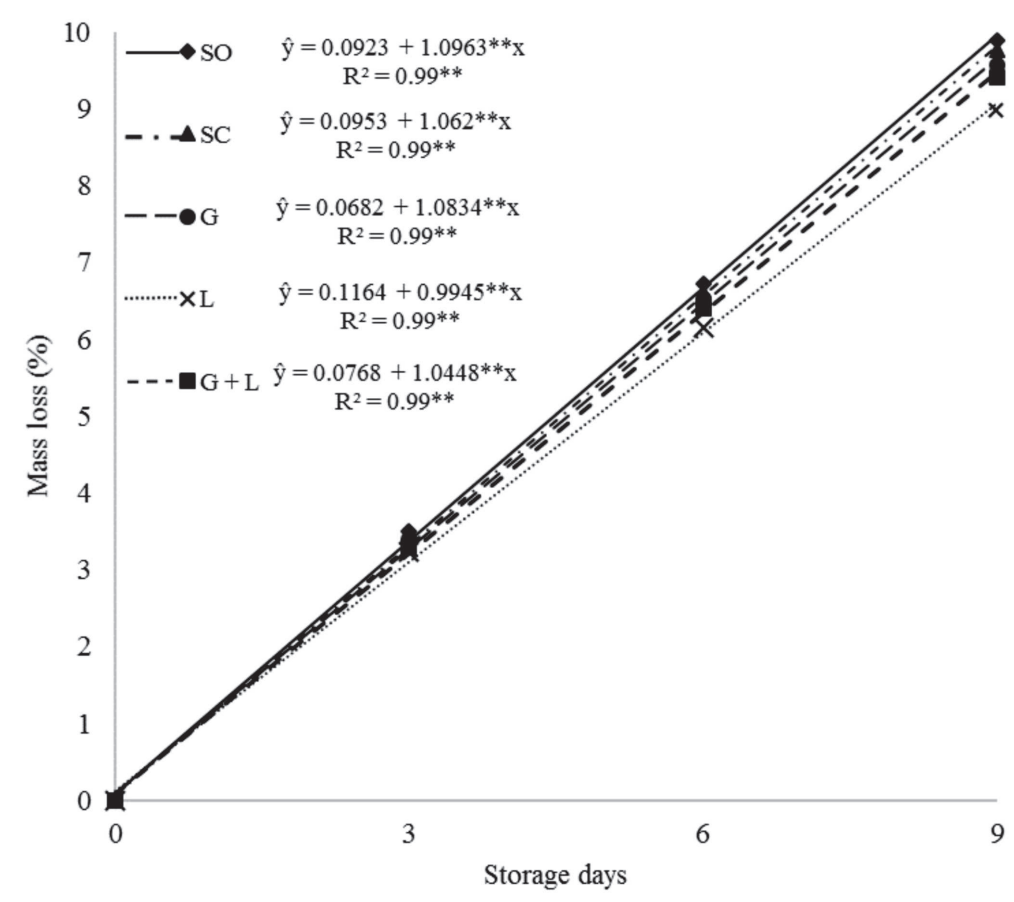

Figure 1: Mass Loss (\%) of maize green ears stored in PVC packaging film, at $25{ }^{\circ} \mathrm{C}$ and $50 \%$ relative humidity, as a function of storage time. $\mathrm{ns}=$ non-significant; $*=$ Significant at $5 \% ; * *=$ Significant at $1 \%$, by the F test. SC - conventional system without straw; SO - organic system without straw; G - SPD organic system with grass straw; L - SPD organic system with legume straw; G $+\mathrm{L}-\mathrm{SPD}$ organic system with grass + legume straw.

Table 3: Analysis of variance of the characteristic mass loss. Domingos Martins, INCAPER, 2014

\begin{tabular}{lcl}
\hline S. V. & D.F. & \multicolumn{1}{c}{ MS } \\
\hline BlocK & 5 & 0.001223 \\
Treatment & 4 & $0.000248^{\text {ns }}$ \\
Error (a) & 20 & 0.000601 \\
Time & 3 & $0.557590^{*}$ \\
Treatment x Tempo & 12 & $0.000043^{\text {ns }}$ \\
Error (b) & 75 & 0.000120 \\
\hline Mean & $0.1884(3.51)$ & \\
\hline CV (\%) of Subplot & 5.81 & \\
\hline
\end{tabular}

* Significant at $5 \%$ probability by the $\mathrm{F}$ test

the results observed by Braz et al. (2006), who found that the hybrids DINA 170 and AG 1051, at room temperature $\left(27^{\circ} \mathrm{C}\right.$ ), had strong fermented odor on the 4th day of storage, disqualifying them for marketing.

The packaging of maize green ears in expanded polystyrene trays covered with PVC film favors the preservation of the product when combined with cooling, however the use of this type of packaging should be careful when not refrigerated. Braz et al. (2006) also found that ears packaged with PVC film kept at room temperature for 4 days storage had a strong fermentation odor.

According to Henz et al. (1996), the validity period of three to five days observed in PVC-packed ears sold in the market should be viewed with reservations when the product is not refrigerated. The data obtained in this experiment confirms this information, since PVC-packed ears kept at room temperature showed fermentation (strong odor) from the fifth day of evaluation.

\section{CONCLUSIONS}

The use of different straws in organic tillage system does not influence the postharvest quality of maize green ears.

Due to the high $\mathrm{pH}$ and low titratable acidity, the maize green ears are considered as a highly perishable product.

Ears packed in polystyrene trays with plastic film are suitable for marketing until the fifth day of storage at room temperature.

\section{REFERENCES}

Albuquerque CJB, Von Pinho RG \& Silva R (2008) Produtividade de híbridos de milho verde experimentais e comerciais. Journal of Biosciense, 24:69-76.

Braz RF, Galvão JCC, Finger FL, Miranda GV, Puiatti M \& Almeida AA (2006) Perda de peso pós-colheita de espigas de milhoverde em função de diferentes formas de acondicionamento. Revista Brasileira de Milho e Sorgo, 5:139-144.

Chitarra AB \& Prado MET (2002) Tecnologia de armazenamento pós-colheita para frutos es hortaliças in natura. Lavras, UFLA/ FAEPE. 112p.

Chitarra MIF \& Chitarra AB (2005) Pós-colheita de frutos e hortaliças: fisiologia e manuseio. $2^{a}$ ed. Lavras, UFLA. 249p. 
Cruz JC, Konzen EA, Pereira Filho IA, Marriel IE, Cruz I, Duarte JO, Oliveira MF \& Alvarenga RC (2006) Produção de milho orgânico na agricultura Familiar. Sete Lagoas, Embrapa-CNPMS. 17p. (Comunicado Técnico, 81).

Embrapa (1999) Sistema brasileiro de classificação de solos. Rio de Janeiro, Embrapa Solos. 412p.

Espírito Santo (1999) Zonas naturais do espírito santo: uma regionalização do estado, das microrregiões e dos municípios/ Secretaria de Estado do Planejamento. Vitória, SEPLAN. 101p.

Finger FL \& Vieira G (1997) Controle da perda pós-colheita de água em produtos hortícolas. Viçosa, UFV. 29p. (Caderno didático, 19).

Henz GP, Nojosa GBA \& Mendonça ND (1996) Conservação póscolheita de espigas de milho-verde cv. AG 519. Horticultura Brasileira, 14:89.

Horwitz W (2005) Official methods of analysis of the Association Analytical Chemists. 18 ${ }^{\mathrm{a}}$ ed. Maryland, AOAC. 1087p.

Kays SJ (1991) Postharvest Physiology of perishable plant products. New York, Van Nostrand Reinhold. 532p.
Mamede AMGN, Chitarra AB, Fonseca MJO, Soares AG, Ferreira JCS \& Lima LCO (2009) Conservação pós-colheita de espigas de milho verde minimamente processado sob diferentes temperaturas. Ciência e Agrotecnologia, 33:200-206.

Marcos SK, Honório SL, Jorge JT \& Avelar JAA (1999) Influência do resfriamento do ambiente de armazenamento e da embalagem sobre o comportamento pós-colheita do milho verde. Revista Brasileira de Engenharia Agrícola e Ambiental, 3:41-44.

Matos MJLF, Tavares SA, Santos FF, Melo MF \& Lana MM (2007) Milho verde. Disponível em: <http://www.cnph.embrapa.br/ laborato/pos_colheita/dicas/milho_verde.htm>. Acessado em: 03 junho de 2014.

Pinho LDE, Paes MCD, Almeida AC \& Costa CA (2008) Qualidade de milho verde cultivado em sistemas de produção orgânico e convencional. Revista Brasileira de Milho e Sorgo, 7:279-290.

Silva PSL, Barreto HEP \& Santos MXA (1997) Avaliação de cultivares de milho quanto ao rendimento de grãos verdes e secos. Pesquisa Agropecuária Brasileira, 32:63-69. 